\title{
Modifications to the 1996 Olympic 3-Day-Events to optimise safety under hot and humid conditions
}

\author{
J. H. Foreman \\ University of Illinois at Urbana-Champaign, College of Veterinary Medicine, Department of Veterinary Clinical Medicine, Urbana, Illinois, USA
}

\begin{abstract}
Summary
Various concerns have been voiced regarding the safety of 3-day-event horses competing in conditions of excessive heat and humidity expected during the next Olympic Summer Games in Atlanta, Georgia USA in 1996. In response, considerable applied research has been conducted recently to characterise the physiological responses of 3-day-event horses and to study how to optimise safety and recovery on speed-and-endurance day. The Fédération Equestre Internationale (FEI) has reduced the maximum required distances for all phases of speed-and-endurance day, lengthened Phase $X$ from 10 to $15 \mathrm{~min}$, and inserted a new veterinary control point, currently termed $\mathrm{C}$ Halt, into Phase $\mathrm{C}$ to allow assisted cooling earlier in the test. FEI has also recommended that horses travel to the USA no less than three weeks prior to Olympic competition to allow for adequate recovery from transport stress and to allow for acclimatisation to typical Georgia summer weather conditions.
\end{abstract}

Keywords: $\quad$ horse, exercise, 3-day-event, heat, humidity

\begin{abstract}
Veränderungen im Ablauf der Vielseitigkeitsprüfung während der Olympischen Spiele 1996, um die Sicherheit an heißen Tagen mit hoher Luftfeuchtigkeit zu verbessern

Um die Sicherheit der Pferde, die bei den Olympischen Sommerspielen 1996 in Atlanta, Georgia USA, in der Vielseitigkeitsprüfung eingesetzt werden, macht man sich viele Gedanken, da sie ihren Wettkampf voraussichtlich bei extrem heißen Temperaturen und hoher Luftfeuchtigkeit absolvieren müssen. Als Reaktion darauf wurde in der letzten Zeit eine beachtliche Anzahl von Feldstudien durchgeführt, um die physiologischen Reaktionen der Vielseitigkeitspferde zu charakterisieren und herauszufinden, wie Sicherheit und Erholung der Pferde am zweiten Tag der Prüfung, dem speed-and-endurance-day, optimiert werden können. So wurden durch die Federation Equestre Internationale (FEI) die maximal vorgeschriebenen Streckenlänge aller Phasen des speed-and-endurance-days verkürzt, die Phase X von 10 auf 15 Minuten verlängert sowie in der Phase $C$ ein zusätzlicher tierärztlicher Kontrollpunkt, genannt $C$ Halt, eingerichtet, um eine assistierte Kühlung der Pferde schon zu einem frühen Zeitpunkt der Prüfung zu ermöglichen. Desweiteren empfiehlt die FEl, daß die Pferde mindestens 3 Wochen vor Beginn der Prüfung in die USA einreisen sollten, um eine vollständige Erholung vom Transportstreß und eine vollständige Akklimatisation an das im Sommer für Georgia typische Wetter zu gewährleisten.
\end{abstract}

Schlüsselwörter: Pferd, Belastung, Vielseitigkeitsprüfung, Hitze, Luftfeuchtigkeit

\section{Introduction}

The next Olympic 3-Day-Events will be held in hot and humid conditions outside Atlanta, Georgia USA in July 1996. Because of a ruling by the International Olympic Committee that two sets of Olympic medals (team and individual) cannot be awarded for only one competition, the team and individual competitions have been separated and, as a consequence, there will actually be two complete 3-day-events in Atlanta. Maximums of 64 and 36 horse/rider pairs will compete in the team and individual competitions, respectively.

The equestrian venue for the 1996 Olympic Games is the Georgia International Horse Park in Conyers, Georgia, approximately 50 $\mathrm{km}$ east of Atlanta. At Conyers, the typical weather for a July day is similar to Atlanta where mean maximum temperatures reach $31-32^{\circ} \mathrm{C}$ at midday and relative humidity $(\mathrm{RH})$ reaches a mean maximum of $70-90 \%$ earlier in the morning. These conditions are believed to be of sufficient severity that several modifications have been proposed to optimise performance and recovery of 3-dayevent horses at these Olympic Games (A. K. Allen and C. W. Kohn, personal communication, 1992; Jeffcott 1994; Kohn and
Hinchcliff 1994; Thomas and Haller 1994; White 1994). Some shortening of the roads-and-tracks was made at Barcelona for the 1992 Olympic 3-Day-Event and more horses finished, relative to the total number of starters, than at any previous Olympic competition (L. B. Jeffcott, personal communication, 1994); Barcelona was, however, less humid than is anticipated in Conyers. Subsequent to the awarding of the Olympic Summer Games to Atlanta, several scientific meetings were held and a cohesive research plan was developed by investigators from the USA, Canada, and the United Kingdom. Several complementary objectives were identified: (1) to establish, clarify, and quantify the severity of the anticipated heat and humidity problem; (2) to determine the best methods for modifying the typical $\mathrm{CCl}^{\star * \star *}$ distances in order to optimise safety and recovery; (3) to apply these recommended modifications to competitive field situations to evaluate their merit; and (4) to determine the minimum time interval needed for Olympic horses to recover from transport stress and to acclimatise to Georgia summer weather conditions before actually competing. 
Defining the severity of the problem

Three research teams approached the objective of defining the severity of the heat and humidity problem. Kohn and Hinchcliff (1995) retrospectively compared typical physiological monitoring data (temperature, pulse, respiratory rate) from one hot 3-dayevent (ambient temperature $25-35^{\circ} \mathrm{C}$ ) and one cool $\left(6-8^{\circ} \mathrm{C}\right)$ weather competition. Significant increases were documented in heart rate, rectal temperature, and especially respiratory rate during and after the speed-and-endurance test in the hot competition. Prospectively, a trotting-galloping-trotting standardised treadmill test was developed under various combinations of $\mathrm{cool} /$ hot and dry/humid laboratory conditions (Kohn et al. 1994). The time to experimental endpoint (defined as pulmonary artery blood temperature $[\mathrm{PAT}]=41^{\circ} \mathrm{C}$ ) was reduced by approximately $50 \%$ when hot/humid tests were compared to cool/dry tests. The conclusion was that the speed-and-endurance test under Conyers conditions needed to be reduced in severity by $50 \%$ from typical northern European conditions.

Marlin and Harris (Harris et al. 1995a; Harris et al. 1995b) developed a treadmill competition exercise test (CET) which simulated 3-day-event distances and speeds under various weather conditions: cool/dry $\left(20^{\circ} \mathrm{C} / 50 \%\right)$, hot/dry $\left(30^{\circ} \mathrm{C} / 50 \%\right)$ and hot/humid $\left(30^{\circ} \mathrm{C} / 80 \%\right)$. Performance was severely diminished under hot/humid conditions. Of the four horses which began the CET under hot/humid conditions, three failed to complete Phase D.

As a prelude to their subsequent research on acclimation, Geor and McCutcheon developed a treadmill standardised exercise test (Geor et al. 1995) similar to that of Kohn et al. (1994). Hot/ humid laboratory conditions led to an increased rate of change of PAT, increased middle gluteal muscle temperature, decreased PAT:skin temperature gradient, and increased heart rate throughout the test. Hot/humid conditions increased the rate of heat storage and delayed heat dissipation after exercise, probably as a result of a decreased core-to-skin temperature gradient.

Similar adverse effects of hot/humid compared to cool/dry conditions were evident from subsequent research on Phase $B$ by Foreman et al. (1995 and 1996). These multicentric investigations verified that trotting unabated during Phase $\mathrm{C}$ under hot/humid conditions adds dramatically to the net heat accumulation of 3day-event horses. Phase $\mathrm{C}$ does not serve as a recovery phase after steeplechase under these conditions; conversely, it adds considerably to the accumulated heat burden. In particular, Kohn et al. (1994) identified $50 \%$ as the amount by which the speedand-endurance test must be modified in order to prevent the development of excessive body core heat loads.

\section{Modifying the FEI distances}

Considerable thought has gone into designing the 1996 Olympic 3-Day-Events to optimise safety for the horses and still maintain competitiveness. The critical question as posed to the researchers by the 1996 Technical Delegate, Hugh Thomas, and the Conyers Course Designer, Roger Haller was: "How do we, under Atlanta conditions, modify Phases B and C so that horses will arrive at Phase $X$ in the same condition as they would when competing under typical northern European conditions?" (R. Haller and H. Thomas, personal communication, 1993; Jeffcott 1994). Foreman and coworkers (1995 and 1996) have investigated this question in various experiments utilising simulated Phases A-B-C$X$ on an inclined treadmill with increased laboratory heat and humidity. Shortening Phase B by $50 \%$ (but not by $25 \%$ ) under hot $\left(26-28^{\circ} \mathrm{C}\right)$ and humid $(80-85 \% \mathrm{RH})$ conditions resulted in significant returns to cool weather (control $20-21^{\circ} \mathrm{C}, 50-60 \% \mathrm{RH}$ ) per- formance in net weight loss, point of fatigue on Phase $C$, recovery heart rate, and plasma lactate (Foreman et al. 1995; Foreman et al. 1996). Andrews et al. (1995) were unable to show improvements in any variable after 15 and $35 \%$ decreases in steeplechase distance in two groups of horses in an actual competition. In this field study, however, less homogeneous groups of horses were examined throughout various portions of a day on which it was not nearly as hot and humid as in Foreman's laboratory experiments.

Phase $\mathrm{C}$ has also been studied in the laboratory in two different experiments (J. H. Foreman, unpublished data, 1994). First, walking initially on Phase $C$ resulted in decreased PAT when compared to trotting, but this improvement lasted only as long as horses walked. Once horses began trotting again in the latter half of Phase C, PAT rose rapidly and was no different than in trials in which horses trotted throughout Phase C.

Second, a new veterinary-supervised cooling area (currently termed $\mathrm{C}$ Halt) was proposed as a method of cooling horses earlier after Phase B under hot and humid conditions. In the laboratory, it was shown that use of one, and especially two, C Halts of only six min in duration significantly decreased PAT and lengthened time to fatigue on Phase C (J. H. Foreman, unpublished data, 1994). Two $\mathrm{C}$ Halts actually decreased PAT throughout the remainder of the test including through the end of the 10-min-long Phase $X$.

The FEI has studied the laboratory data and other recommendations carefully and has already reduced the maximum distances required for the 1996 Olympic Summer Games 3-Day-Events. Typical and reduced distances for the various phases are listed in Tab. 1. The reduced distances are maximums, and as such they may be reduced further if ambient conditions warrant immediately prior to the competition. At a pre-Olympic venue test called The Atlanta Cup in August 1995, the days preceding speed-and-endurance day had maximum midday temperatures $>39^{\circ} \mathrm{C}$, so similar reductions of the maximum distances were made as late as the day before speed-and-endurance day, and with favourable results. Additionally, the length of the "vet box" (Phase X) has been extended from 10 to 15 min for Atlanta to allow additional recovery and more veterinary scrutiny before Phase $D$.

It has also been agreed that the first horse for the 1996 Olympic Games 3-Day-Events will be "on course" at first daylight. All horses in the team competition are to complete the speed-and-endurance test no later than 11:30 hrs. The individual competition

Tab. 1: Standard FEl maximum distances $(\mathrm{m})$ for $\mathrm{CCl}^{\star * * *}$ 3-dayevents and reduced maximum distances approved by FEl for the team and individual 3-day-events to be held in Atlanta in July 1996 as part of the Olympic Summer Games.

\begin{tabular}{|l|c|c|}
\hline Phase & $\begin{array}{l}\text { FEl Maximum Distances } \\
\text { for a Standard CCl****} \\
\text { 3-Day-Event }(\mathrm{m})\end{array}$ & $\begin{array}{l}\text { FEI Maximum Distances } \\
\text { for the 1996 Atlanta } \\
\text { Olympic 3-Day-Events }(\mathrm{m})\end{array}$ \\
\hline A & 7,480 & 5,000 \\
B & 3,450 & 2,760 \\
C & 11,220 & 7,700 \\
D & 7,980 & 6,270 \\
\hline Total & 30,130 & 21,730 \\
\hline
\end{tabular}


should be concluded much earlier since fewer horse/rider pairs will compete. Since the team competition is now strictly a team competition, it has been agreed that the test may be modified (e.g., shortened in distance, possibly with fewer jumping efforts), should conditions become unexpectedly severe, between the second and third, or more likely between the third and fourth, flights of horses to go out as the morning progresses. That is, before the fourth horse of the first team in the competition starts Phase A, the course may be shortened for that and for all of the fourth horses for each team. Finally, several groups of trained and practiced volunteers will be available at $\mathrm{C}$ Halt, $\mathrm{X}$, various intervals throughout $D$, and the end of $D$ to help any team or individual which needs assistance in cooling horses under inclement conditions.

\section{Field applications of laboratory research}

In order to test the efficacy of the recommended modifications under competitive situations, three field studies of the effects of modified 3-day-events were performed in 1994-1995. Andrews et al. (1995) studied the effects of shortening steeplechase at the 1994 Bluegrass 3-Day-Event and Horse Trials in Lexington, Kentucky and showed no benefits from shortening steeplechase by 15 and $35 \%$. The study was constrained, however, by several uncontrollable factors since this was an actual competition: (1) groups were not randomised as to order-of-go or as to ability level; (2) when steeplechase distance was shortened, Phase C distance was lengthened commensurately so that all horses competed over the same total $\mathrm{B}+\mathrm{C}$ distance; (3) horses were heterogeneous as to ability, training, feeding, and riding; (4) the nature of the competition restricted the number of measurements which could be made; and (5) the weather was less than severe (20$29^{\circ} \mathrm{C}$ and $\left.39-49 \% \mathrm{RH}\right)$. The fact that these variables were out of the control of the investigators only underscores the frustrating and uncontrollable nature of field studies.

In August 1994, a simulated CCl* was held in Chatsworth, Georgia to test many of the principles which had been outlined by laboratory research. Two groups of American horses and one group of European horses completed shortened $\mathrm{CCl}^{*}$ distances with either one (European) or two (American) C Halts inserted early in Phase C. Due to concerns over inclement weather and humane care of client-owned research subjects, a positive control group performing unmodified $\mathrm{CCl}^{\star}$ distances was not utilised. There were few demonstrable differences between the groups (Kohn et al. 1995; Hinchcliff et al. 1995). It was concluded that a safe 3-day-event was possible under hot Georgia summer weather conditions. Because (1) the weather was not terribly severe and (2) these horses were not performing $\mathrm{CCl}^{\star \star \star *}$ distances, the caveats were made that safe 3-day-events were possible for the 1996 Olympic Summer Games if there were shortening of $\mathrm{CCl}^{* * * *}$ distances and if further modifications were allowed should ambient conditions warrant them.

In August 1995, The Atlanta Cup CCl ${ }^{\star *}$ and Advanced Horse Trials were held on the Olympic venue in Conyers to test all aspects of the Olympic site, from housing to safety on course. In the Advanced Horse Trials, which were run under American Horse Shows Association rules, only Phases $A$ and $D$ were completed but at $\mathrm{CCl}^{\star \star \star}$ distances over the future Olympic footing. As the week began, conditions were relatively inhospitable $\left(>38^{\circ} \mathrm{C}\right.$ at $12: 00 \mathrm{hrs}$ ), so modifications were made to allow shortening of Phases B, C, and D and insertion of a C Halt. As the week progressed, conditions worsened $\left(>39^{\circ} \mathrm{C}\right)$ and the Ground Jury responded appropriately by insertion of a second $\mathrm{C}$ Halt and additional shortening of Phases $C$ and D. The conditions on speed-and- endurance day eased somewhat but the test was left at its last modified version as of 14:00 hrs the day prior. Competitors and veterinary staff agreed afterward that the modifications were helpful and appropriate in assisting horses (and riders) in dealing with the hot/humid conditions.

C Halts of varying length (3-10 min) have now been used at actual USA competitions at Essex, New Jersey (1994); AHSA/Kimberly-Clark Field Trial, Chatsworth, Georgia (August 1994); North American Young Riders Championships, Wadsworth, Illinois (August 1995); and The Atlanta Cup, Conyers, Georgia (August 1995). Riders have welcomed the additional respite during a hot/humid Phase C; they often seem to benefit as much, if not more so, than do the horses. The $\mathrm{C}$ Halt also allows for earlier detection of injuries after steeplechase, thus preventing the injured horse having to complete all of Phase $\mathrm{C}$ (over 60 min of trotting at $\mathrm{CCl}^{\star * * *}$ competitions).

\section{When should horses arrive?}

Acclimation is defined as adaptation to environmental stress (heat, humidity, cold) in the laboratory, whereas acclimatisation is adaptation in an actual field setting. Geor and McCutcheon have reported that most of the changes associated with acclimation in horses have occurred within the first 14 days of exposure to increased heat and humidity (Geor et al. 1995; McCutcheon et al. 1995; Geor et al. 1996). These adaptations included decreased exercise-induced body weight loss (by day 15) and heart rate elevation (by day 10: Geor et al. 1996). Sweating mechanisms also showed acclimation since peak sweating rate and sweat sodium concentration decreased (McCutcheon et al. 1995).

Marlin and coworkers (1996) have studied acclimation of five horses trained for 14 days at $30^{\circ} \mathrm{C} / 80 \% \mathrm{RH}$ but living in nonacclimating stalls at $4-10^{\circ} \mathrm{C}$. This heat training led to an improvement in performance in hot/humid CET performance since four of five horses were able to complete or nearly complete the CET after acclimation (a $16 \%$ increase in exercise time) but none completed it prior to acclimation. Resting and exercising rectal temperature decreased by approximately $1^{\circ} \mathrm{C}$ after six days of acclimation. Sweating occurred at a lower skin temperature, but sweat rates were lower during and after exercise. In addition, preceding the AHSA/Kimberly-Clark Field Trial in August 1994, Marlin studied the European horses before and after air transport to the USA and during their acclimatisation period in Georgia (D.J. Marlin, unpublished data, 1994). It was concluded that approximately one week was needed to recover from transport stress and a further two weeks were necessary to provide sufficient acclimatisation to allow training to continue at the same level as prior to transport. Based on research in Canada (Geor et al. 1995; McCutcheon et al. 1995; Geor et al. 1996) and England (Marlin et al. 1996), current $\mathrm{FEl}$ recommendations are that horses should arrive a minimum of three weeks prior to the Olympic Games in 1996. There are currently no data to support a need to arrive any earlier than three weeks.

\section{References}

Andrews, F. A., White, S. A., Williamson, L. H., Maykuth, P. L., Geiser, D. R., Green, E. M., Ralston, S. L. and Mannsmann, R. A. (1995): Effects of shortening the steeplechase phase (Phase B) of a 3-dayevent. Equine vet. J. Suppl. 20, 64-72.

Foreman, J. H., Grubb, T. L., Benson, G. J., Frey, L. P., Foglia, R. A. and Griffin, R. L. (1995): Physiological effects of shortening steeplechase in a 3-day-event. Equine vet. J. Suppl. 20, 73-77. 
Foreman, J. H., Grubb, T. L., Benson, G. J., Frey, L. P., Foglia, R. A. and Griffin, R. L. (1996): Acid-base and electrolyte effects of shortening steeplechase in a 3-day-event. Equine vet. J. Suppl. 22, submitted, under review.

Geor, R. J., McCutcheon, L. J., Ecker, G. L. and Lindinger, M. (1995): Thermal and cardiorespiratory responses of horses to submaximal exercise under hot and humid conditions. Equine vet. J. Suppl. 20, 125-132.

Geor, R. J., McCutcheon, L. J. and Lindinger, M. I. (1995): Exercise heat tolerance in Thoroughbred horses associated with a 21-day period of heat acclimation. Abstract in: Proc of International Conference on Dehydration, Rehydration and Exercise in the Heat, Nottingham, England.

Geor, R. J., McCutcheon, L. J. and Lindinger, M. I. (1996): Adaptations to daily exercise ain hot and humid ambient conditions in trained Thoroughbred horses. Equine vet. J. Suppl. 22, submitted, under review.

Harris, P. A., Marlin, D. J., Mills, P. C., Roberts, C. A., Scott, C. M., Harris, R. C., Michell, A. R., Orme, C. E., Schroter, R. C., Marr, C. M. and Barrelet, F. (1995a): Clinical observations made in nonheat acclimated horses performing treadmill exercise in cool $\left(20^{\circ} \mathrm{C} / 40 \%\right.$ $\mathrm{RH})$, hot, dry $\left(30^{\circ} \mathrm{C} / 40 \% \mathrm{RH}\right)$ or hot, humid $\left(30^{\circ} \mathrm{C} / 80 \% \mathrm{RH}\right)$ conditions. Equine vet. J. Suppl. 20, 78-84.

Harris, P. A., Marlin, D. J., Scott, C. M., Harris, R. C., Mills, P. C., Michell, A. R., Orme, C. E., Roberts, C. A., Schroter, R. C., Marr, C. M. and Barrelet, F. (1995b): Electrolyte and total protein changes in nonheat acclimated horses performing treadmill exercise in cool $\left(20^{\circ} \mathrm{C} / 40 \% \mathrm{RH}\right)$, hot, dry $\left(30^{\circ} \mathrm{C} / 40 \% \mathrm{RH}\right)$ or hot, humid $\left(30^{\circ} \mathrm{C} /\right.$ $80 \% \mathrm{RH}$ ) conditions. Equine vet. J. Suppl. 20, 85-96.

Hinchcliff, K. W., Kohn, C. W., Geor, R., McCutcheon, L. J., Foreman, J., Andrews, F. M., Allen, A. K., White, S. L., Williamson, L. H. and Maykuth, P. L. (1995): Acid:base and serum biochemistry changes in horses competing at a modified 1 Star 3-day-event. Equine vet. J. Suppl. 20, 105-110.

Jeffcott, L. B. (1994): Progress towards Atlanta '96: Background to the FEl research initiative. In: On To Atlanta '96, Eds.: A. F. Clarke and L. B. Jeffcott. Equine Research Centre, University of Guelph, Guelph, Ontario, Canada, pp. 2-7.

Kohn, C. W., Hinchcliff, K. W. and McKeever, K. (1994): Effects of ambient temperature and humidity on performance in exercising horses. In: On To Atlanta '96, Eds.: A. F. Clarke and L. B. Jeffcott. Equine Research Centre, University of Guelph, Guelph, Ontario, Canada, pp. 69-71.

Kohn, C. W. and Hinchcliff, K. W. (1994): Maximizing performance of event horses in hot, humid weather: A field trial. In: Proc. 40th Annual Conv. Am. Assoc. Equine Practnr., p. 77.
Kohn, C. W. and Hinchcliff, K. W. (1995): Physiological responses to the endurance test of a 3-day-event during hot and cool weather. Equine vet. J. Suppl. 20, 31-36.

Kohn, C. W., Hinchcliff, K. W., McCutcheon, L. J., Geor, R., Foreman, J., Allen, A. K., White, S. L., Maykuth, P. L. and Williamson, L. H. (1995): Physiological responses of horses competing at a modified 1 Star 3-day-event. Equine vet. J. Suppl. 20, 97-104.

Marlin, D. J., Scott, C. M., Schroter, R. C., Mills, P. C., Roberts, C. A., Harris, R. C. and Harris, P. A. (1996): Acclimation of horses to high temperature and humidity. Pferedheilkunde, submitted, under review.

McCutcheon, L. J., Geor, R. J. and Lindinger, M. I. (1995): Sweating rate and sweat composition during heat acclimation in Thoroughbred horses. Abstract in: Proc of International Conference on Dehydration, Rehydration and Exercise in the Heat, Nottingham, England.

Thomas, H. and Haller, R. (1994): Considerations in planning the Olympic Three Day Event course. In: On To Atlanta '96, Eds.: A. F. Clarke and L. B. Jeffcott. Equine Research Centre, University of Guelph, Guelph, Ontario, Canada, p. 17.

White, S.L. (1994): Olympic equestrian games, Atlanta 1996: Are we asking too much? In: Proc. 40th Annual Conv. Am. Assoc: Equine Practnr., pp. 79-80.Table 1

\section{Acknowledgements}

Supported in part by the American Horse Shows Association Equine Health Research Fund, United States Department of Agriculture Animal Health Formula Funds and the Maria Caleel Fund for Equine Sports Medicine Research at the University of Illinois.

\section{J. H. Foreman}

University of Illinois at Urbana-Champaign

College of Veterinary Medicine

Department of Veterinary Clinical Medicine

1008 West Hazelwood Drive, Urbana

Illinois 61801, USA

Tel. (002 17) 3332000

Fax (002 17) 2441475 